\title{
Hydraulic model for water management along Dâmbovița River through Bucharest City, Romania
}

\author{
Daniela Elena Gogoașe Nistoran ${ }^{1,}$, Cristina Sorana Ionescu ${ }^{1}$, Mihail Georgescu ${ }^{2}$, and Doruleț Stefan David ${ }^{2}$ \\ ${ }^{1}$ University Politehnica of Bucharest, Power Engineering Faculty, Hydraulics, Hydraulic Machinery and Environmental Engineering \\ Department, 313 Spl. Independenței, Bucharest, Romania \\ "Romanian Waters" National Administration
}

\begin{abstract}
The main objective of the paper is to simulate the steady state flow conditions along the regulated Dambovița River in Bucharest City. The canal has 11 reaches in series separated by control structures with gated weirs (barrages). The simulations are performed using the 1D HEC-RAS software for flows between 3 and $45 \mathrm{~m}^{3} / \mathrm{s}$, in order to find the optimal opening of each set of gates, so that water levels along reaches are kept at the target Normal Pool Levels (NPL) elevation. For the determined operating situations optimized gate openings and gates' rating curves are drawn. The computed water surface profiles for the maximum flow allow for checking if the banks are flooded, whereas velocity values for the minimum, ecological flow of $3 \mathrm{~m}^{3} / \mathrm{s}$ highlight the reaches over which the biota could be affected during summer drought periods. This model could assist the Water Management Authority's technical staff to better operate the gates in an integrated manner. Since currently gate operations are individually performed at each control structure, such a model would be a primary step in designing and implementing an automatic controlling system for the entire Dambovița canal in Bucharest City.
\end{abstract}

\section{Introduction}

Most of the large cities were developed along river banks for reasons of water consumption, transportation, trade, culture, sewage [1]. Cities' urbanization, coupled with economic and social development, placed an increasing pressure on river systems, watershed hydrology, water quantity and quality, groundwater, on flood risk and overall on river integration with nature [2], [3]). Many river crossing cities were subject to intensive engineering works over time such as channelization, regulation, rectification, diversion, construction of dams, hydropower plants, dikes, locks, sewage systems, etc.

Recently, riverine water fronts are considered important assets to be restored as part of urban redevelopment schemes $[4,5]$. Such schemes are designed to protect cities from flooding and/or for other uses, such as navigation and tourism, aiming at meeting engineering needs and achieve sustainable development goals. Therefore, adjustment of water level or flow is very important, and many models and controllers were developed by professionals to optimally control these parameters at different hydraulic structures (gates, locks, outlet valves, weirs, etc.), for different operation conditions (particularily for large canals, such as North Sea, Amsterdan-Rhine, Meuse, Kiev, etc.) [6-10],

Dambovița River is a first order tributary of Argeș River and a second one of Danube River. It has a length of $237 \mathrm{~km}$ and a catchment area of $2,837 \mathrm{~km}^{2}$. The river crosses from N-W to S-E Bucharest, Romania's capital city (with a population of about 2 million people and a surface area of about $228 \mathrm{~km}^{2}$ ). Although Dambovița River has an annual flow of only $12 \mathrm{~m}^{3} / \mathrm{s}$ (upstream Bucharest), it has a high disaster flooding potential that led to several important city floods over time, of which most important were in $1774\left(\mathrm{Q}_{\max }=220 \mathrm{~m}^{3} / \mathrm{s}\right), 1862$, $1865,1975\left(650 \mathrm{~m}^{3} / \mathrm{s}\right)[11]$.

Since Dambovița River channel was also a sewage and storm water collector, there was an urgent need for a rapidly growing population into a modernizing city to plan and implement a redevelopment scheme. Such scheme would involve dams, reservoirs, intakes and complex inter-basin water diversion canals with other rivers or reservoirs located in or existing nearby Bucharest city [12-14].

Therefore, during 1985-1990 engineering works for the "Complex Management Scheme of the Dâmboviţa River in Bucharest" were developed by the national water authorities. The project had several purposes:

(i) to protect the city from flooding, by the upstream Morii Reservoir (Lacul Morii in Romanian) impounded by Ciurel Dam of $15 \mathrm{~m}$ in height (built earlier, in the 80 's). The reservoir has a maximum water surface area of 220 ha and a maximum storage capacity of 14.7 million $\mathrm{m}^{3}$. It has also been designed for leisure purposes;

(ii) to regulate and channelize Dambovița River flow through a trapezoidal canal (called "clean water" canal) along a distance of about $17 \mathrm{~km}$. The natural river channel has been reshaped by increasing the water depth along the river through 11 reaches in series (pools)

* Corresponding author: dnistoran@gmail.com 
separated by control structures with gated broad-crested weirs (barrages) [15]. Several quays were also built along the canal for tourism and navigation purposes;

(iii) to collect and transport wastewater, rainwater and groundwater through closed sewage collectors placed underneath Dambovița canal.

The present paper proposes to develop and implement a 1D hydraulic numerical model that simulates the flow through the Dambovița canal and its barrages - control structures by using the HEC-RAS software [16-17]. The model seeks to find the optimal opening of each set of gates for flows up to $45 \mathrm{~m}^{3} / \mathrm{s}$ (maximum allowable discharge through the canal), so that water level in pools are kept at the Normal Operating Pool levels indicated by the designer, National Institute of Research and Design for Water Management (IRDWM).
Figure 1 depicts a plan view of the Morii Reservoir and the developed Dambovița River across Bucharest and its neighbouring areas. Latitude and longitude of the reservoir centre are $44^{\circ} 27^{\prime} 18^{\prime \prime} \mathrm{N}$ and $26^{\circ} 01^{\prime} 39^{\prime} ' \mathrm{E}$, respectively.

The location of the 11 control structures is shown on the map whereas their main geometrical and hydraulic features are presented in Table 1 (in which NPL is Normal Pool Level, U/S distance is distance with respect to upstream barrage). The last two downstream $(\mathrm{D} / \mathrm{S})$ control structures along Dambovița River are located outside Bucharest. Each of the barrage is equipped with either one or three flap (tilting) gates that can be operated to control the water level in the upstream reach.

Mean longitudinal slope of Dambovița canal along all reaches is between 0.07 and $1.5 \% 0$ [15].

\section{Site and data}

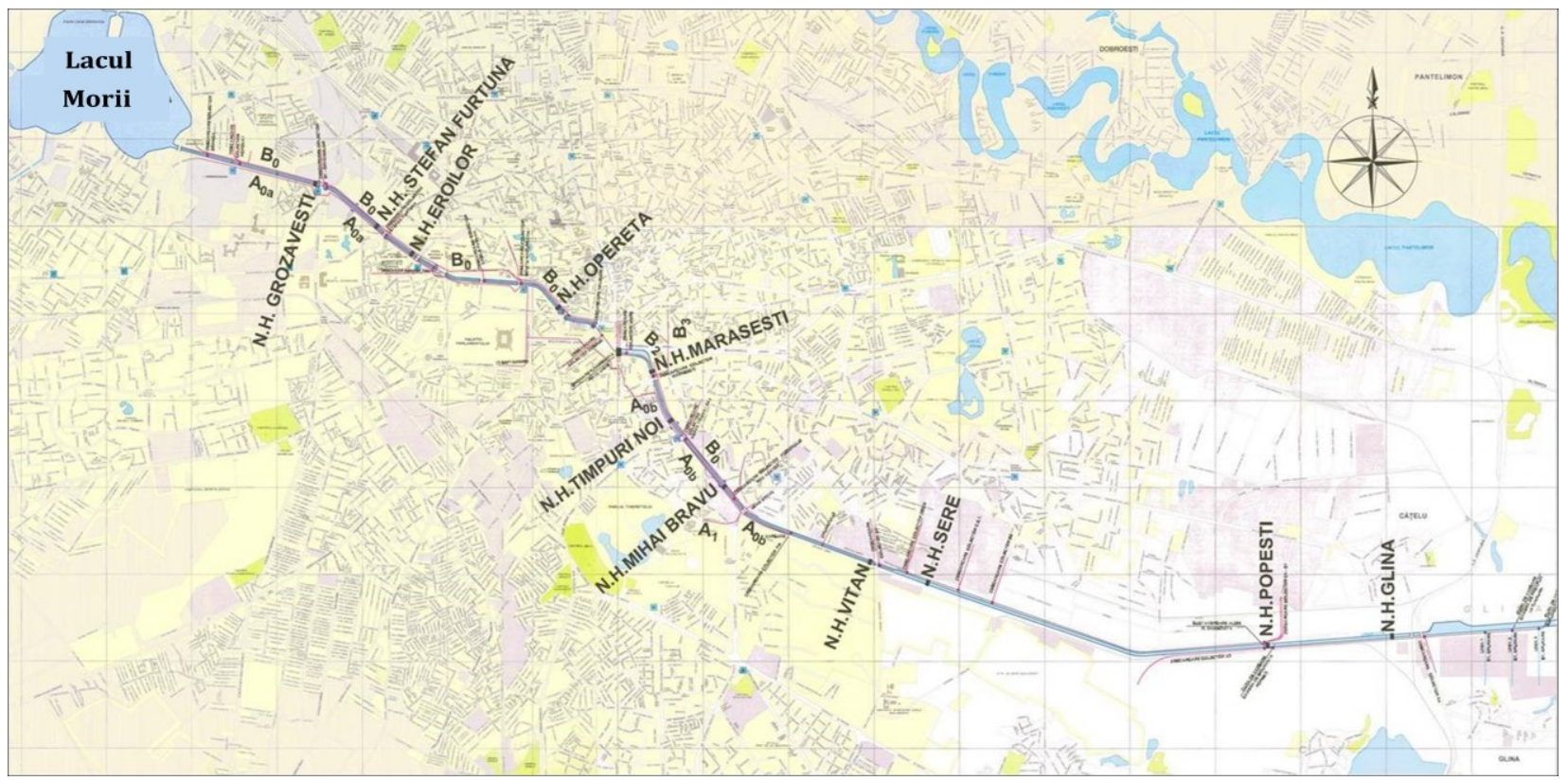

Fig. 1. Plan view of Dambovița River through Bucharest City, with the 11 control structures (N.H. - "nod hidrotehnic" in Romanian).

Table 1. Geometrical features of Dambovița control structures.

\begin{tabular}{|c|l|c|c|c|c|c|}
\hline $\begin{array}{c}\text { Con- } \\
\text { trol } \\
\text { struc } \\
\text { ture } \\
\text { no. }\end{array}$ & $\begin{array}{l}\text { Name of } \\
\text { barrage } \\
\text { - control } \\
\text { structure }\end{array}$ & $\begin{array}{c}\text { No } \\
\text { of } \\
\text { gates }\end{array}$ & $\begin{array}{c}\text { gate } \\
\text { width }\end{array}$ & $\begin{array}{c}\text { gate } \\
\text { max. } \\
\text { ope- } \\
\text { ning }\end{array}$ & $\begin{array}{c}\text { NPL } \\
\text { elev. } \\
\text { (BS) }\end{array}$ & $\begin{array}{c}\text { U/S } \\
\text { dis- } \\
\text { tance }\end{array}$ \\
\hline 13 & $\begin{array}{l}\text { Groza- } \\
\text { vești }\end{array}$ & 1 & 28 & 2.8 & 74.8 & 1720 \\
\hline 12 & $\begin{array}{l}\text { Ștefan } \\
\text { Furtună }\end{array}$ & 3 & 7.5 & 1.4 & 73.3 & 886 \\
\hline 11 & Eroilor & 1 & 24 & 2.85 & 72.5 & 558 \\
\hline 10 & Operetă & 3 & 7.5 & 1.4 & 71.3 & 1896 \\
\hline 9 & $\begin{array}{l}\text { U/S } \\
\text { Unirii }\end{array}$ & & & & & \\
\hline & culvert & - & - & - & n.a. & 501.6 \\
\hline
\end{tabular}

\begin{tabular}{|c|l|c|c|c|c|c|}
\hline 8 & $\begin{array}{l}\text { D/S } \\
\text { Unirii } \\
\text { culvert }\end{array}$ & - & - & - & n.a. & 421 \\
\hline 7 & $\begin{array}{l}\text { Mara- } \\
\text { șesti }\end{array}$ & 3 & 6 & 1.4 & 69.3 & 1465 \\
\hline 6 & $\begin{array}{l}\text { Timpuri } \\
\text { Noi }\end{array}$ & 3 & 6 & 1.4 & 68.4 & 583 \\
\hline 5 & $\begin{array}{l}\text { M. } \\
\text { Bravu }\end{array}$ & 3 & 6 & 1.4 & 67.3 & 962 \\
\hline 4 & Vitan & 3 & 7.5 & 1.4 & 65 & 2007 \\
\hline 3 & Sere & 3 & 7.5 & 1.4 & 63 & 630 \\
\hline 2 & Popești & 3 & 8 & 2.3 & 59 & 4110 \\
\hline 1 & Glina & 3 & 8 & 2.3 & 54.5 & 1904 \\
\hline
\end{tabular}

Between control structures no. 7 and 10 the water flows through a culvert underneath Unirii Square: $9-$ upstream $(\mathrm{U} / \mathrm{S})$ inlet and 8 downstream outlet $(\mathrm{D} / \mathrm{S})$. The 
geometry of this culvert is very complex since it includes two underground old bridges that lead to a reduction of flow cross-section. As discharge increases over a certain limit $\left(40-45 \mathrm{~m}^{3} / \mathrm{s}\right.$ from in-situ observations) a transition occurs from free-surface to full - flow (under pressure flow) conditions also causing the water level to raise and potentially flood Unirii Square. This limits the maximum discharge that can be transported along Dambovița canal.

The requirement to comply with ecological flow also limits minimum value of the discharge to $2.5 \div 3 \mathrm{~m}^{3} / \mathrm{s}$ [15]. Intermediate discharge values of about $20 \mathrm{~m}^{3} / \mathrm{s}$ are required for periodic cleaning flush.

Figure 2 presents a typical cross-section profile of the concrete-lined Dambovița canal (example along $\mathrm{M}$. Bravu - Vitan reach) in which one can see the sewage collectors underneath the invert / floor level. The top width is larger than the one of the natural river and varies between 30 and $100 \mathrm{~m}$ (between cross-sections 8 and 7). Depths can vary between $1.5 \div 4.5 \mathrm{~m}$ whereas mean bank slope is of 1.5 along the entire canal for NPL elevation.

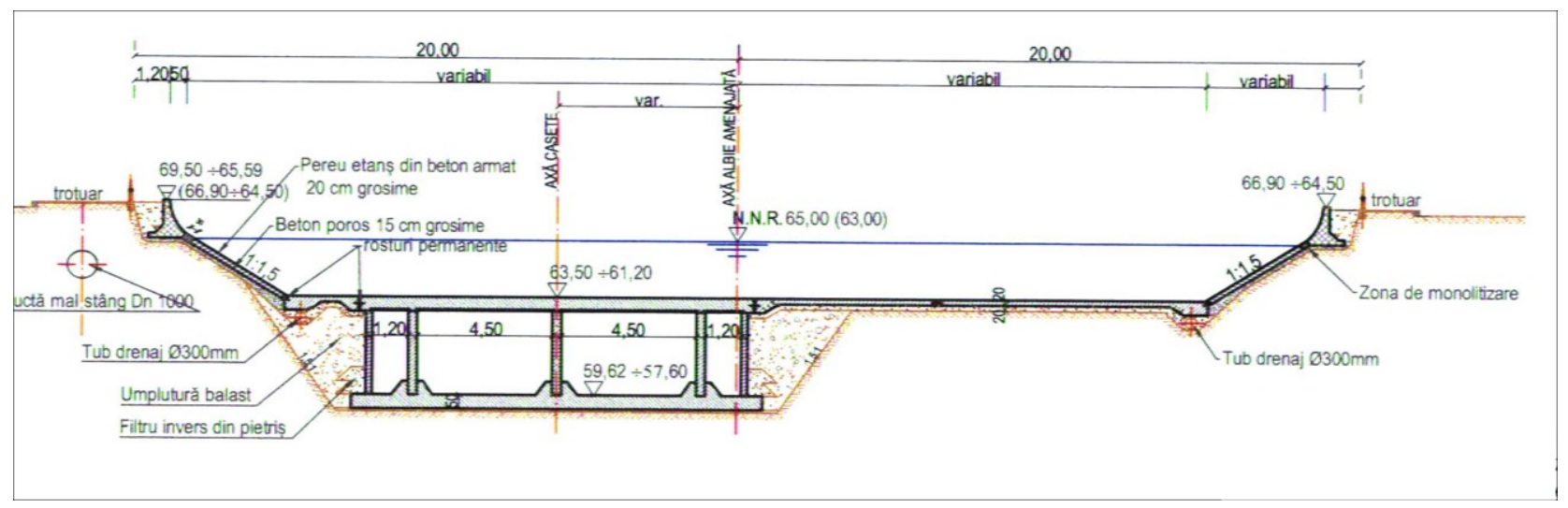

Fig. 2. Typical design cross-section profile of Dambovița canal (Mihai Bravu - Vitan reach).

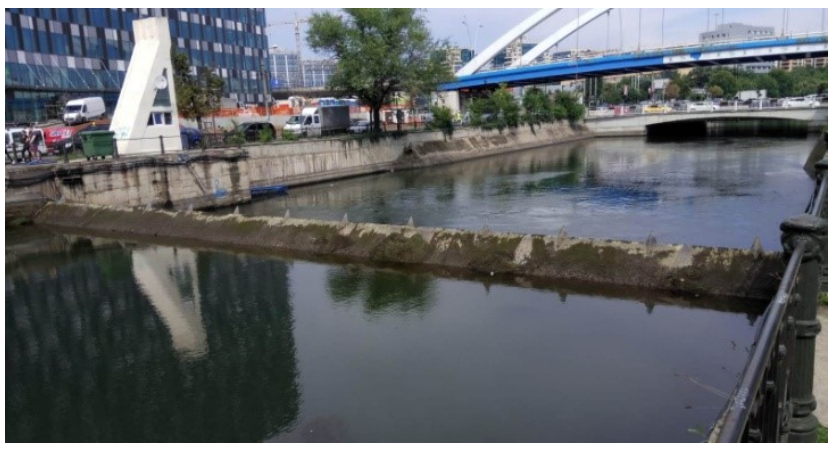

Fig. 3. Typical control structure with one gate (12. Grozăvești).

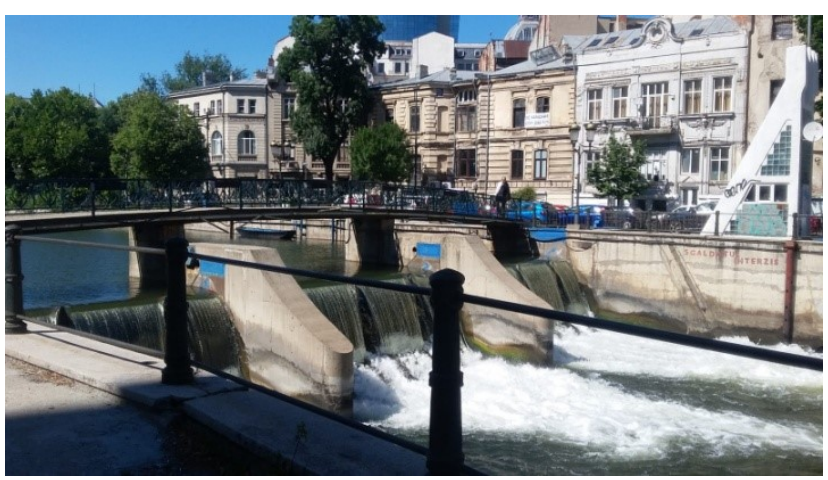

Fig. 4. Typical control structure with three gates (10. Operetă).

The widest gate along Dambovița canal at Grozăvești control structure is shown in figure 3 and an example of three-gate-system from 10. - Operetă control structure is presented in figure 4. By lowering the gates, the water levels U/S the barrages are controlled, so that large flows can be routed without flooding the pedestrian ways and streets along the banks [18].

\section{Method}

A one-dimensional model implemented in HEC-RAS software [16] was considered to reproduce the hydraulic behaviour of this $17 \mathrm{~km}$ reach, along which the main hydrodynamic variables (velocity, depth) change predominantly in one direction [19].

The geometry of the canal was modeled using crosssection profiles along the 11 reaches and design geometrical features of the control structures with gated weirs (figure 5).

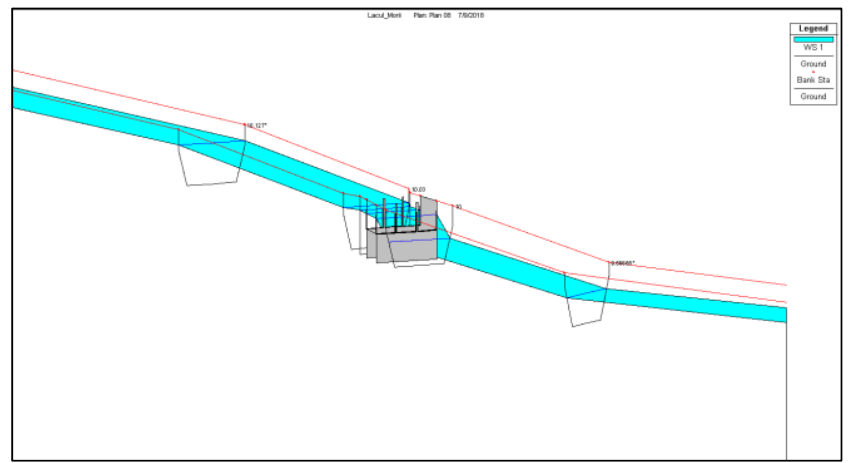

Fig. 5. 3D view example of a modeled control structure with gated weir along Dambovița River canal.

Geometrical interpolations were performed every $200 \mathrm{~m}$. Even though each gate from a set may be independently operated, for water nappe shape-related esthetical reasons, in practice, they are operated simultaneously (figure 6). Moreover, the gates can be moved to allow any opening between 0 and their maximum height. 
Due to the fact that HEC-RAS can only simulate radial and sluice gates, the geometry of existing flap gates and their operation mode were simplified (figure. 6 ). Thus, they were chosen as vertical overflow sluice gates. Additionally, their discharge coefficient is considered to remain constant with the head.

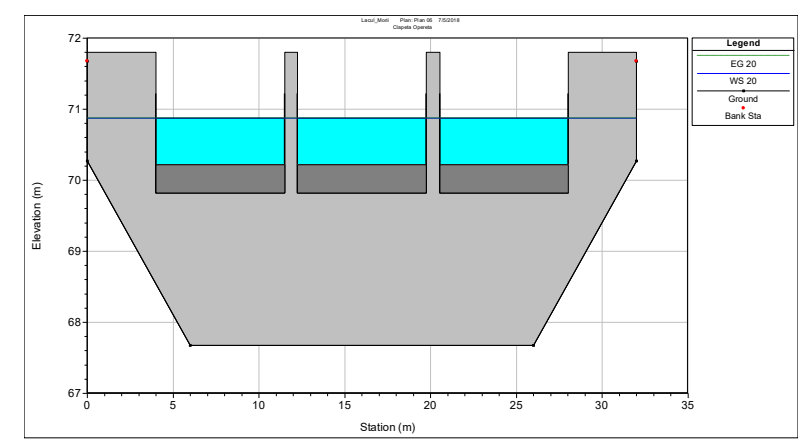

Fig. 6. Example of a modeled gated-weir cross-section at a control structure.

The simplified geometry of the Unirii Square culvert as implemented in the 1D model is shown in figure 7.

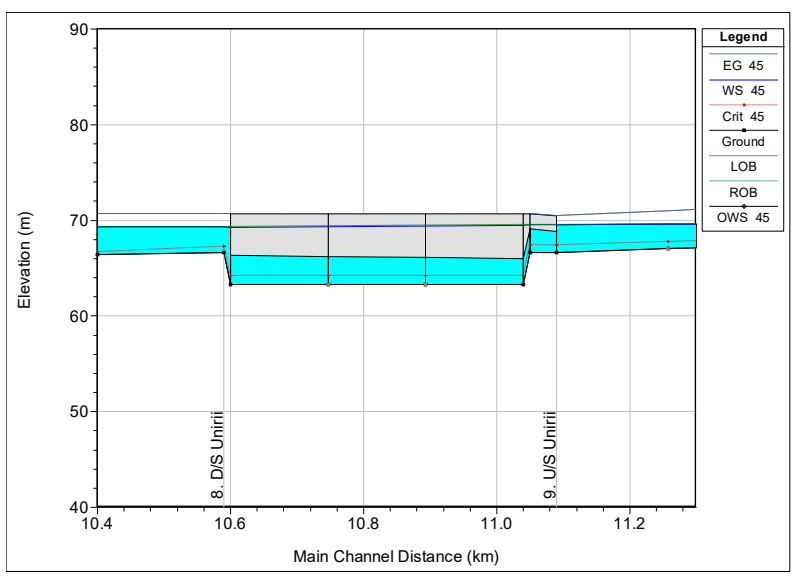

Fig. 7. Modeled culvert from Unirii Square.

Almost all barrages are placed upstream of bridges so that the latter would not be flooded. Therefore, another simplifying assumption was to neglect the influence of bridges upon flow.

Computations were performed starting from the downstream end of the canal for the gradually varied flow under steady state flow conditions by using the standard step finite difference method [20-22] along an elementary computation reach bounded by two consecutive cross-sections ( $\mathrm{i}-\mathrm{D} / \mathrm{S}$ and $\mathrm{i}+1-\mathrm{U} / \mathrm{S})$ :

$$
\begin{aligned}
z_{i+1}-z_{i}= & -\frac{Q^{2}}{\bar{K}^{2}}\left(x_{i+1}-x_{i}\right)- \\
& -\zeta \frac{\alpha Q^{2}}{2 g}\left|\frac{1}{A_{i+1}^{2}}-\frac{1}{A_{i}^{2}}\right|-\frac{\alpha Q^{2}}{2 g}\left(\frac{1}{A_{i+1}^{2}}-\frac{1}{A_{i}^{2}}\right)
\end{aligned}
$$

in which:

$z$ is the water level in a cross-section;

$A$ - the wetted area in a cross-section;

$x$ - the $\mathrm{D} / \mathrm{S}$ distance;

$\bar{K}$ - the average conveyance along the computation reach which takes into account the friction losses;

$\zeta$ - the contraction-expansion coefficient; $\alpha$ - the Coriolis velocity coefficient.

Boundary conditions were constant discharge values at the U/S end (Ciurel Dam) and uniform flow (slope) at the $\mathrm{D} / \mathrm{S}$ end of the canal.

When the upstream cross-section is at a gated weir, iterations are performed to find the optimal opening that matches imposed upstream Normal Operating Pool elevations. The opening is computed by using the formula:

$$
Q_{r}=C_{d} \sqrt{2 g} B H^{3 / 2}=C H^{3 / 2}
$$

where:

$C_{d}$ is the non-dimensional discharge coefficient taken 0.4 as suggested by Chadwick and Morfett [16] to take into account friction and contraction,

$H$ - the head over the gate crest,

$B$ - total width of the gate openings and

$C$ - the dimensional discharge coefficient that includes the acceleration due to gravity.

\section{Results and discussions}

The hydraulic model was calibrated on water level values observed at 9 of the control structures for a maximum flow of $45 \mathrm{~m}^{3} / \mathrm{s}$ by adjusting the Manning roughness coefficient in all cross-sections. All gates were fully opened, as in operation.

Table 2 presents a comparison between observed and computed water level values (measured with respect to Black Sea - BS level) and their errors relative to depth (or pressure head in case of Unirii culvert).

As it may be seen, the maximum error relative to pressure head has an acceptable value of 5\%, except for the cross-section of U/S Unirii Square culvert. This large difference between observed and computed level values may be attributed to the complex geometry and the transition from an open channel flow to pressurized flow, which cannot be handled by the used 1D model.

Table 2. Measured and computed water levels for $\mathrm{Q}=45 \mathrm{~m}^{3} / \mathrm{s}$.

\begin{tabular}{|l|c|c|c|c|}
\hline $\begin{array}{c}\text { Control } \\
\text { structure }\end{array}$ & z meas. & z comp. & $\begin{array}{c}\text { z meas.- } \\
\text { z comp. }\end{array}$ & $\begin{array}{c}\text { Relative } \\
\text { error }\end{array}$ \\
\hline no./ name & m (BS) & $\mathbf{m ~ ( B S )}$ & $\mathbf{m}$ & $\%$ \\
\hline 5. M. Bravu & 67.23 & 67.14 & 0.09 & 3.3 \\
\hline $\begin{array}{l}\text { 6. Timpuri } \\
\text { Noi }\end{array}$ & 68.33 & 68.29 & 0.04 & 1.3 \\
\hline 7. Marășești & 69.25 & 69.3 & -0.05 & 1.5 \\
\hline $\begin{array}{l}\text { 9. U/S } \\
\text { Unirii Sq. }\end{array}$ & 70.7 & 69.53 & 1.17 & 22 \\
\hline 10. Operetă & 70.99 & 70.97 & 0.02 & 0.6 \\
\hline 11. Eroilor & 71.19 & 71.09 & 0.1 & 4 \\
\hline $\begin{array}{l}\text { 12/ Stefan } \\
\text { Furtună }\end{array}$ & 73.53 & 73.42 & 0.11 & 2 \\
\hline $\begin{array}{l}\text { 13. Groză- } \\
\text { vești }\end{array}$ & 73.63 & 73.46 & 0.16 & 4.9 \\
\hline $\begin{array}{l}\text { 14. Ciurel } \\
\text { Dam }\end{array}$ & 84.99 & 85 & -0.01 & \\
\hline
\end{tabular}


Therefore, the hydraulic model was assumed to be a good approximation of the steady-state flow conditions along Dambovița River canal except for the Unirii Square culvert.

A set of discharge values in the range of $3 \div 45 \mathrm{~m}^{3} / \mathrm{s}$ were used to run the model with gate opening optimization in order to maintain the NPL elevations in the U/S of each barrage.
Figure 8 shows the water surface profiles along the reaches together with the NPL elevations (red points) for three of the considered discharge values: 3, 20 and $45 \mathrm{~m}^{3} / \mathrm{s}$. It may be seen that the banks (green dotted lines) are not flooded and the most important backwater effect occurs along the second $\mathrm{D} / \mathrm{S}$ reach (Popești Sere).

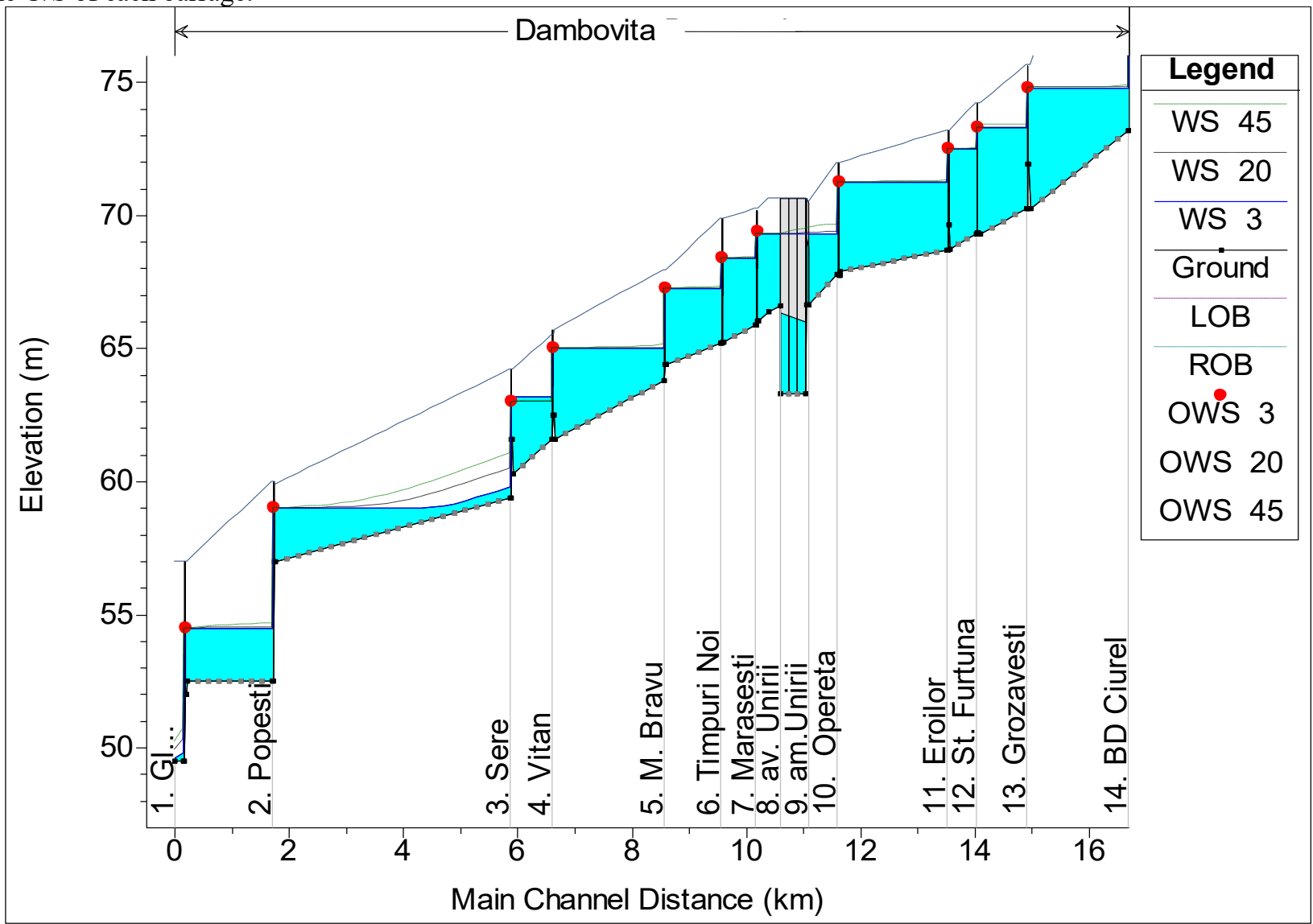

Fig. 8. Water surface profiles along Dambovița River canal for three discharge values: 3,20 and $45 \mathrm{~m}^{3} / \mathrm{s}$ (WS - water surface OWS observed water surfaces, LOB/ROB - left/right overbank elevations).

Figure 9 depicts the resulted gate openings for the considered discharge range at the first $9 \mathrm{U} / \mathrm{S}$ control structures in Bucharest City. As it may be seen, NPL elevations could be maintained for all gates and discharge values except at St. Furtună barrage for flows exceeding $35 \mathrm{~m}^{3} / \mathrm{s}$.

Three rating curves obtained through gate-opening optimization are presented in figure 10. It may be seen that the water surface elevation is maintained at NPL, except for Șt. Furtună barrage at maximum discharge $\left(45 \mathrm{~m}^{3} / \mathrm{s}\right)$.

For the ecological flow of $3 \mathrm{~m}^{3} / \mathrm{s}$ it is useful to compute the mean velocities in all cross sections in order to highlight the reaches with minimum velocities. Thus, operating staff of Dambovița River could apply specific measures to prevent or limit undesired phenomena such as water vegetation proliferation and biota life threatening conditions, particularly during drought periods.

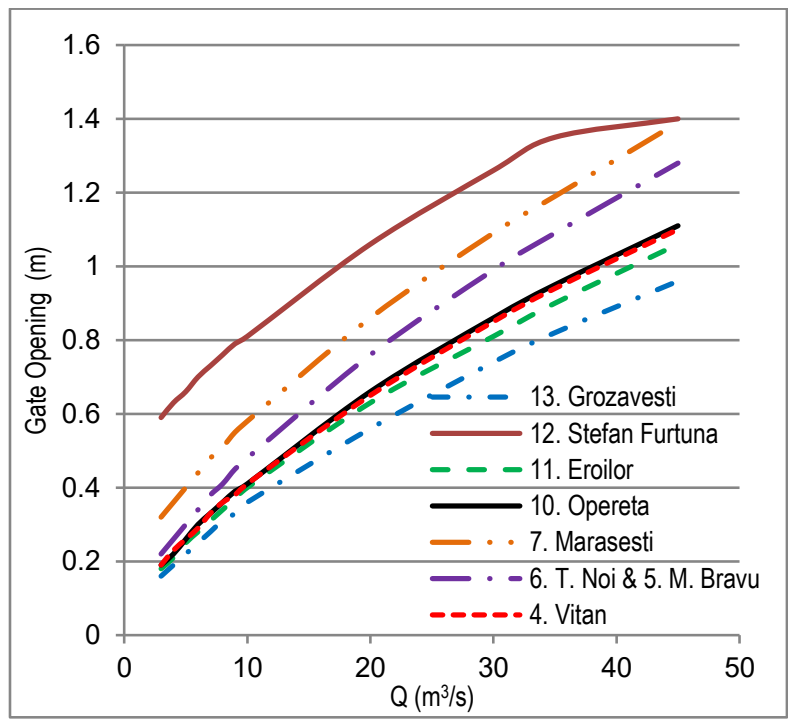

Fig. 9. Optimized gate openings for NPL elevations U/S of each barrage. 


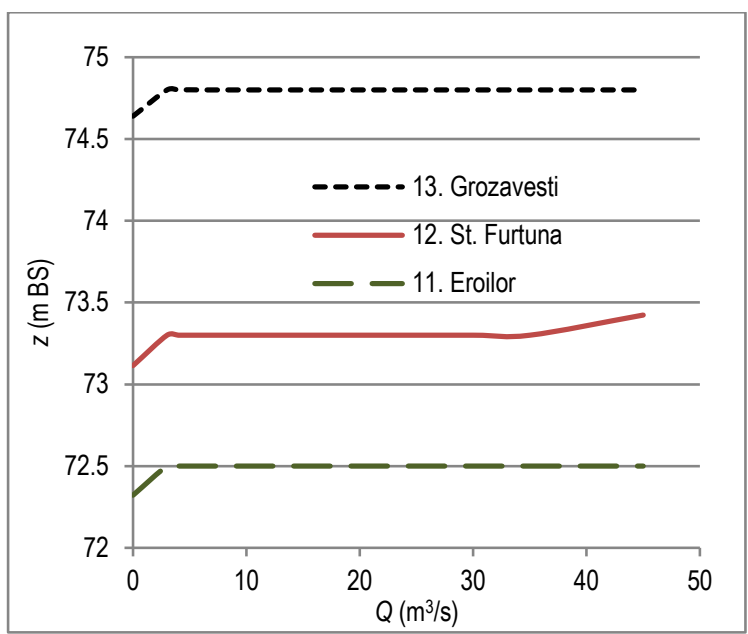

Fig. 10. Examples of modified rating curves after gate-opening optimization.

Under the considered operation scenario, the computed velocities along Dambovița canal are shown in figure 11, for three discharge values $(3,20$ and $45 \mathrm{~m} 3 / \mathrm{s})$. As it may be seen, the control structures with barrages increase local velocity through contraction, also contributing to the aeration of the stream. For the minimum flow, velocities may drop to $1 \mathrm{~cm} / \mathrm{s}$ in the critical enlarged reach located between the exit of Unirii Square culvert and Marașești control structure.

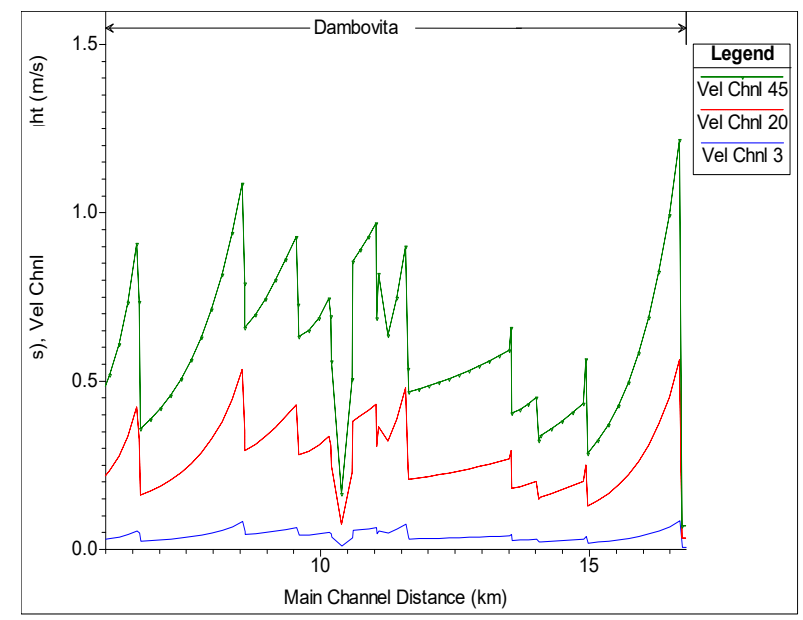

Fig. 11. Computed mean velocities along Dambovița canal for three discharge values: 3, 20 and $45 \mathrm{~m}^{3} / \mathrm{s}$; ("Vel Chnl" - crosssection mean velocity in the River canal).

\section{Conclusions}

The paper proposes a 1D hydraulic model using the HEC-RAS software to simulate the flow along Dambovița regulated River reach flowing through Bucharest City. The following simplifying assumptions were made for the 11 control structures with barrages built along the canal: (i) existing flap gates are modeled as vertical overflow sluice gates and (ii) gate discharge coefficients are assumed to be constant for any opening and head values.

An optimization procedure is applied to find out the best openings of the gates so that water levels can be maintained at the target NPL elevation U/S each barrage.
For this case and the entire flow range of discharges (between 3-45 $\mathrm{m}^{3} / \mathrm{s}$ ) that can be transported along Dambovița, rating curves as well as water surface profiles were computed and plotted. Only for the Ștefan Furtună control structure at maximum discharge the NPL elevation could not be maintained even if the gate was fully opened.

Simulated velocities are useful indicators for monitoring critical reaches with minimum values, mainly during summer periods.

The HEC-RAS model could be further improved by including the existing bridges and used as a first approximation for routing flood waves along Dambovița canal considering different scenarios for gate openings to avoid the flooding of the banks and the bridges.

The main shortcoming of the model is that it could not reproduce the complex geometry and transition from open channel to pressure flow at the Unirii Square culvert. For this area a 3D model is recommended.

Further calibration of individual gated-weir' discharge coefficients should be performed on measurements carried out at each control structure.

However, this model could assist the Water Management Authority's technical staff to better operate the gates in an integrated manner. Since currently gate operations are individually performed at each barrage, such a model would be a primary step in designing and implementing an automatic operation system for the entire Dambovița River throughout Bucharest City.

\section{References}

1. D. L. Feldman, The Water-Sustainable City, Science, Policy and Practice (Edward Elgar Publishing Ltd., 2017)

2. M. O. Driscoll, A. Jefferson, S. M. Clinton, A. K. Manda, Water, 2, $605 \quad$ (2010) http://doi:10.3390/w2030605

3. Y. Wen, P. James, Y. Kai, Impact of urbanization on structure and function of river system. Case study of Shanghai, China, Chinese Geogr. Sci., 16, 102 (2006) http://dx.doi.org/10.1007/s11769-006-0002-9

4. S. Castonguay, M. Evenden, Urban Rivers. Remaking Rivers, Cities, and Space in Europe and North America, (Univ. of Pittsburgh Press, 2012)

5. J. Shuurmans, W. Shuurmans, H. Berger, M. Meulenberg, R. Brower, J. Irrig. Drain. E.-ASCE, 123(3), 180

(1997)

https://ascelibrary.org/doi/10.1061/ \%28ASCE\%290733-9437\%281997\%29123\%3A3 \%28180\%29

6. P.-O. Malaterre, D. C. Rogers, J. Shuurmans, Classification of Canal Control Algorithms, J. Irrig. Drain. E.-ASCE, 124(1): 3 (1998) https://doi.org/10.1061/(ASCE)07339437(1998)124:1(3)

7. J. Shuurmans, A. Hof, S. Dijkstra, O. H. Bosgra, R. Brower, J. Irrig. Drain. E., 125(4): 189-195 (1999) https://ascelibrary.org/doi/10.1061/\%28ASCE\%290 733-9437\%281999\%29125\%3A4\%28189\%29 
8. P.J. van Overloop, R. R. Negenborn, B. de Schutter, N.C. van de Giesen, Predictive Control for national water flow optimization in the Netherlands, Chapter 17 in Intelligent Infrastructures, R.R. Negenborn, B. de Schutter, Z. Luskzo, H. Hellendorn, 42, Intelligent Systems, Control and Automation: Science and Engineering, Dordrecht, The Netherlands: Springer, 439, (2010) https://link. springer.com/chapter/10.1007/978-90-481-3598117

9. P. J. van Overloop, J. Shuurmans, C. Burt, J. Irrig. Drain. E.-ASCE, 131(2), 190 (2005) https://doi.org/ 10.1061/(ASCE)0733-9437(2005)131:2(190)

10. X. Litrico, G. Bellaut, J.-P. Baume, J. Ribot- Brumo, J. Irrig. Drain. E.-ASCE, 131(2), 176 (2005) https://doi.org/10.1061/(ASCE)0733-9437(2005) 131:2(176)

11. M. Radu, Present Environment and Sustainable Development, 2, $366 \quad$ (2008) http://pesd.ro/articole/nr.2/33.\%20Radu PESD 200 $\underline{\text { 8.pdf }}$

12. P. Solacolu, Integrating the complex watermanagement scheme of Dambovita River within the river-basin management plans (in Romanian), Revista Hidrotehnica, 26, 76 (1988)

13. C. Popescu, F. Lăzărescu, General design concept of the regulated Dambovița River in Bucharest (in Romanian), Revista Hidrotehnica, 33, 3 (1988)

14. L. Zaharia, G. Ioana-Toroimac, O. Cocoş, F.A. Ghiţă, E. Mailat, Urbanization effects on the river systems in the Bucharest City region (Romania), Ecosystem Health and Sustainability, 2 (11), 1 (2016) https://doi.org/10.1002/ehs2.1247

15. ***, "Romanian Waters" National Administration, Operation Rules for the management of Dambovița River downstream Morii Reservoir, Internal Report, in Romanian, (1993)

16. ***, USACE - United States Army Corps of Engineers, HEC-RAS, Hydrologic Engineering Centre- River Analysis System, User Manual, Version 5 (2016) http://www.hec.usace.army.mil /software/hec-ras/

17. C. Goodell, Advance Gate Operation Strategies in HEC-RAS 5.0, In B. Crookston \& B. Tullis, Hydraulic Structures and Water System Management, $6^{\text {th }}$ IAHR International Symposium on Hydraulic Structures, Portland, OR, 27-30 June, 519 (2016)

https://www.google.com/url?sa=t\&rct=j\&q=\&esrc= s\&source=web\&cd $=1 \&$ ved $=2$ ahUKEwi5t5C $8 \mathrm{zYbe}$ AhWHs4sKHaSlATwQFjAAegQICBAC\&url=https $\% 3 \mathrm{~A} \% 2 \mathrm{~F} \% 2 \mathrm{Fdigitalcommons.usu.edu} \% 2 \mathrm{Fcgi} \% 2 \mathrm{Fv}$ iewcontent.cgi $\% 3$ Farticle $\% 3 \mathrm{D} 1070 \% 26$ context $\% 3 \mathrm{D}$ ishs\&usg=AOvVaw3EwyCbd5zJKgAfNAsRwux

18. G. Flegont, D. Lungu, G. Metoni, E. Predescu, Control structures of Dambovița river management system in Bucharest (in Romanian), Revista Hidrotehnica, 33, 39 (1988)
19. E. Carvajal, R. Huber, F. Geiger, P. Rutshmann, One- and three-dimensional modeling of surge generated during operation of the hydropower plants Mühlbach and Maiermühle in Landsberg on the Lech River, Conf. River Flow 2010, (2010)

20. F. M. Henderson, Open Channel Hydraulics (Macmillan, 1966)

21. D. Nistoran, F. Moatăr, M. Manoliu and C. Ionescu, Engineering hydraulics (in Romanian), (Printech, 2007)

22. A. Chadwick, J. Morfett, Hydraulics in Civil and Environmental Engineering, II edition, (E. and FN SPON, 1994) 